p-ISSN : 2597-8977

e-ISSN : 2597-8985

Universitas Negeri Makassar

Ratnawaty Mamin

Universitas Negeri Makassar

Erika Nadya Nastiti

Universitas Negeri Makassar

\section{PENGARUH MODEL PEMBELAJARAN KOOPERATIF TIPE TEAM ASSISTED INDIVIDUALIZATION (TAI) TERHADAP HASIL BELAJAR PESERTA DIDIK KELAS VIII SMP NEGERI 18 MAKASSAR (Studi pada Materi Pokok Alat Optik)}

Abstrak: Penelitian ini bertujuan untuk mengetahui adakah pengaruh model pembelajaran kooperatif tipe Team Assisted Individualization (TAI) terhadap hasil belajar peserta didik kelas VIII SMP Negeri 18 Makassar (Studi pada Materi Pokok Alat Optik). Penelitian ini adalah penelitian quasi experiment menggunakan desain penelitian Pretest-Posttest Noneqivalent Control Group Design. Populasi penelitian ini adalah seluruh kelas VIII SMP Negeri 18 Makassar semester genap tahun pelajaran 2016/2017 yang berjumlah 10 kelas. Adapun sampel penelitian ini dilakukan dengan cara double random sampling dengan asumsi bahwa seluruh kelas adalah homogen. Pengambilan data penelitian dilakukan dengan menggunakan tes hasil belajar. Analisis data dilakukan dengan menggunakan uji-t. Hasil analisis data dengan menggunakan uji-t menunjukkan bahwa $\mathrm{H}_{1}$ diterima pada $a=0,05$. Dengan demikian dapat disimpulkan bahwa 1) Hasil belajar peserta didik yang dibelajarkan dengan menggunakan model pembelajaran kooperatif tipe team assisted individualization (TAI) berada pada kategori sangat tinggi, dan hasil belajar peserta didik yang dibelajarkan dengan model pembelajaran direct instruction berada pada kategori sedang. 2) Hasil belajar peserta didik yang dibelajarkan dengan menggunakan model pembelajaran kooperatif tipe team assisted individualization (TAI) lebih tinggi daripada hasil belajar peserta didik yang dibelajarkan dengan model pembelajaran direct instruction dengan hasil $t_{\text {hitung }}=4,67>t_{\text {tabel }(0,58)}=1,67$. Hal ini menunjukkan bahwa penggunaan model pembelajaran kooperatif tipe team assisted individualization berpengaruh terhadap hasil belajar peserta didik.

Kata Kunci: Kooperatif, Team Assisted Individualization (TAI), Hasil belajar

Abstract: This research purpose to determine is there any influence of cooperative learning type Team Assisted Individualization (TAI) towards the learning outcomes of students in class VIII SMPN 18 Makassar (Main Study About Optical). This research is a quasi-experiment research by using the research design of pretest-posttest noneqivalent control group design. The study population was the entire class VIII SMPN 18 Makassar, second semester of academic year 2016/2017, amounting to 10 classes. The sample of this rearch is done by double-random sampling assuming that the entire class is homogeneous. Data retrieval of research is done by using achievement test. Data analysis was performed using t-test. The results of data analysis using t-test showed that $\mathrm{H}_{1}$ received at $\alpha=0.05$. It can be concluded that 1) The outcome of learners that learned using cooperative 
learning typeteam assisted individualization (TAl) is in the very high category, and the outcome of students that learned by direct instruction is in the middle category. 2) The outcome of learners that learned using cooperative learning type team assisted individualization (TAl) is higher than the outcome of students that learned by direct instruction with the results of $t_{\text {count }}=4.67>t_{\text {table }}(0.58)=1.67$. This shows that the use of cooperative learning type team assisted individualization influenced the learning outcomes of students.

Keywords: Cooperative, Team Assisted Individualization (TAI), Learning Outcomes

\section{PENDAHULUAN}

Salah satu tujuan Pendidikan Nasional Bangsa Indonesia sebagaimana tercantum dalam Pembukaan Undang-Undang Dasar Negara Republik Indonesia tahun 1945 adalah mencerdaskan kehidupan bangsa. Pencapaian tujuan ini dilakukan melalui pendidikan yang melibatkan kegiatan belajar dan proses pembelajaran.

Undang-Undang Sistem Pendidikan Nasional No. 20 Tahun 2003 Pasal 3 mengisyaratkan adanya upaya-upaya untuk mengembangkan kemampuan peserta didik agar mereka lebih berilmu, cakap, kreatif dan tanggungjawab. Dalam proses pembelajaran di kelas, tidak terkecuali dalam pembelajaran IPA harus terus diupayakan peningkatan-peningkatan kearah berkembangnya kemampuan peserta didik.

Pendidikan merupakan salah satu faktor untuk membentuk pribada manusia. Dengan pendidikan, manusia dapat dipandang terhormat, memiliki karier yang baik, dan kecerdasan yang dapat membuat dirinya berguna di masyarakat. Pendidikan yang dilaksanakan dengan kualitas tinggi pasti akan menghasilkan sumber daya manusia yang berkualitas. Dengan melihat pentingnya pendidikan bagi diri sendiri dan orang lain, maka pemerintah selalu memperbaiki sistem pendidikan di Indonesia dari waktu ke waktu seiring dengan berkembangnya zaman.

Salah satu alasan seringnya pemerintah memperbaiki sistem pendidikan di Indonesia yaitu karena dalam dunia pendidikan, peneliti masih sering menemukan peserta didik yang memiliki nilai hasil belajar yang rendah misalnya pada mata pelajaran IPA dimana kebanyakan pendidik masih menggunakan model pembelajaran konvensional yang menggunakan metode ceramah dan pemberian tugas. Penggunaan metode mengajar ceramah oleh pendidik masih kurang optimal karena menjadikan peserta didik kurang aktif dalam pembelajaran dan penerapan metode pemberian tugas menjadikan peserta didik bosan. Padahal dalam pembelajaran IPA peserta didik harus dilibatkan secara aktif untuk membuktikan sendiri kebenaran teori yang telah dipelajari. Berdasarkan hal tersebut, hasil belajar peserta didik seringkali masih jauh di bawah standar.

Berdasarkan hasil observasi yang dilakukan pada Bulan Januari 2017 di SMPN 18 Makassar, bahwa nilai hasil belajar IPA peserta didik masih rendah. Nilai rata-rata adalah $65,59 \%$, dimana peserta didik yang tuntas yaitu 46,87\% sedangkan tidak tuntas yaitu 53,13\%. Hal tersebut dikarenakan kurangnya minat, motivasi dan semangat belajar dari peserta didik itu sendiri. Masih kurangnya minat, motivasi dan semangat belajar peserta didik dikarenakan pendidik masih menggunakan model pembelajaran konvensional yang menggunakan metode ceramah dan pemberian tugas. Penggunaan metode ceramah oleh pendidik masih kurang optimal karena menjadikan peserta didik kurang aktif dalam pembelajaran dan penerapan metode pemberian tugas menjadikan peserta didik bosan sehingga mengakibatkan nilai hasil belajar yang masih rendah. Dengan melihat kondisi tersebut, maka perlu diterapkan pendekatan pembelajaran yang 
membuat peserta didik terlibat secara aktif dalam proses pembelajaran sehingga dapat meningkatkan hasil belajar peserta didik.

Pemilihan model pembelajaran yang sesuai dengan tujuan kurikulum dan kompetensi peserta didik merupakan kemampuan dan keterampilan dasar yang harus dimiliki oleh seorang pendidik. Hal ini didasari oleh asumsi bahwa ketepatan pendidik dalam memilih model akan berpengaruh terhadap keberhasilan dan hasil belajar peserta didik. Salah satu model pembelajaran yang dapat digunakan untuk meningkatkan keberhasilan dan hasil belajar peserta didik.

Model pembelajaran kooperatif merupakan proses pembelajaran secara berkelompok yang dapat mendukung suatu proses pembelajaran, dimana peserta didik dapat mudah memahami pelajaran yang sulit dengan mendiskusikan dengan teman kelompok. Salah satu model pembelajaran kooperatif yang dapat digunakan untuk meningkatkan keberhasilan dan hasil belajar peserta didik adalah model pembelajaran kooperatif tipe Team Assisted Individualization (TAI).

Model pembelajaran kooperatif tipe Team Assisted Individualization (TAI) merupakan model pembelajaran yang mengkombinasikan pembelajaran kooperatif dan pembelajaran individual. Model kooperatif ini dirancang untuk mengatasi kesulitan belajar peserta didik secara individual dalam suatu kelompok. Model pembelajaran ini menerapkan pola belajar bimbingan antar teman yaitu peserta didik yang pandai, bertanggung jawab terhadap peserta didik yang kurang pandai. Sehingga dengan penerapan model pembelajaran kooperatif tipe TAI ini diharapkan dapat meningkatkan hasil belajar.

Ilmu Pengetahuan Alam (IPA) merupakan ilmu yang mempelajari tentang gejala-gejala alam yang meliputi makhluk hidup dan makhluk tak hidup. Ilmu Pengetahun Alam adalah program untuk menanamkan dan mengembangkan pengetahuan, keterampilan, sikap dan nilai ilmiah pada peserta didik hingga mencintai dan menghargai kebesaran Tuhan Yang Maha Esa. Ilmu Pengetahuan Alam diharapkan dapat menjadi wahana bagi peserta didik untuk mempelajari diri sendiri dan alam sekitar, serta perbaikan dan pengembangan untuk menerapkannya dalam kehidupan sehari-hari.

Salah satu materi pada mata pelajaran IPA di SMP adalah Alat Optik. Peserta didik diharapkan dapat mengenal dan mempelajari dirinya sendiri melalui pemahaman terhadap alat optik. Peserta didik akan menyadari bahwa tubuh yang dimiliki telah diatur sedemikian rupa. Peserta didik akan semakin memahami makna ke-Mahabesaran Tuhan yang telah menciptakan segala sesuatu tanpa sia-sia.

Model pembelajaran kooperatif dikembangkan untuk mencapai setidak-tidaknya tiga tujuan pembelajaran penting. Menurut depdiknas tujuan pertama pembelajaran kooperatif, yaitu meningkatkan hasil akademik, sedangkan tujuan kedua memberi peluang agar peserta didik dapat menerima teman-temannya yang mempunyai berbagai perbedaan latar belajar, kemudian tujuan ketiga untuk mengembangkan keterampilan sosial peserta didik (Taniredja, 2012).

Salah satu pendekatan atau strategi dalam model pembelajaran kooperatif ialah model pembelajaran tipe Team Assisted Individualization (TAI). TAI dikembangkan untuk beberapa alasan. Pertama, kami berharap agar TAI menyediakan cara penggabungan kekuatan motivasi dan bantuan teman sekelas pada pembelajaran kooperatif dengan program pengajaran individual yang mampu memberi semua peserta didik materi yang sesuai dengan tingkat kemampuan mereka dalam bidang matematika dan memungkinkan mereka untuk memulai materi-materi ini berdasarkan kemampuan mereka sendiri. Kedua, kami mengembangkan TAI untuk menerapkan teknik pembelajaran kooperatif untuk memecahkan banyak maslaah pengajaran individual, pada tahun 1960-an, pengajaran individual dan metode-metode yang serupa diharapkan bisa merevolusi pengajaran, terutama dalam matematika (Slavin, 2010).

Dalam metode TAI, peserta didik dikelompokkan berdasarkan kemampuannya beragam. Masing-masing kelompok terdiri dari 5 peserta didik dan ditugaskan untuk menyelesaikan materi pembelajaran. Ada awalanya, jenis metode ini dirancang khusus untuk mengajarakan matematika atau terampilan menghitung kepada peserta didik-peserta didik SD kelas 3-6. Akan tetapi, pada 
perkembangan berikutnya, metode ini mulai diterapkan pada materi-materi peajaran yang berbeda. Dalam metode TAl, setiap kelompok diberi serangkaian tugas tertentu untuk dikerjakan bersama-sama. Poin-poin dalam tugas dibagikan secara berurutan kepada setiap anggota (misalnya untuk materi matematika yang terdiri dari 8 soal, berarti 4 anggota alam setiap kelompok harus saling bergantian menjawab soal-soal tersebut). Semua anggota harus saling mengecek jawaban teman-teman satu kelompoknyadan saling memberi bantuan jika memang dibutuhkan (Huda, 2013).

Setelah itu, masing-masing anggota diberi tes individu tanpa bantuan dari anggota yang lain. Selama menjalani tes individu ini, pendidik harus memerhatikan setiap peserta didik. Skor tidak hanya dinilai oleh sejauh mana peserta didik mampu menjalani tes itu, tetapi juga sejauh mana mereka mampu bekerja secara mandiri (tidak mencontek). Setiap minggu, pendidik menjumlahkan ada berapa banyak soal yang bisa dijawab oleh masing-masing kelompok penghargaan (reward) diberkan kepada kelompok yang mampu menjawab soal-soal dengan benar lebih banyak dan mampu menyelesaiakan PR dengan baik. Pendidik memberikan poin tambahan (extra point) kepada individu-individuu peserta didik yang mampu meperroleh nlai rata-rata pada ujian final. Karena dalam metode TAI peserta didik harus saling mengecek pekerjaannya satu sama lain dan mengerjaka tugas berdasarkan rangkaian soal tertentu, pendidik sambil lalu bisa member penjelasan seputar soalsoal yang kebanyakan dianggap rumit oleh peserta didik. Dalam metode TAI ini, akuntabilitas individu, kesempatan yang sama untuk sukses, dan dinamika motivasional menjadi unsur-unsur utama yang harus ditekankan oleh pendidik (Huda, 2013).

Kelebihan model pembelajaran kooperatif tipe TAI (Slavin, 2009) yaitu :

a. Model pembelajaran kooperatif tipe TAI dapat meningkatkan hasil belajar dan motivasi belajar peserta didik.

b. Model pembelajaran tipe TAI dapat membantu meningkatkan kemampuan pemecahan masalah peserta didik.

c. Melatih peserta didik untuk bekerja secara kelompok, melatih keharmonisan dalam hidup bersama atas dasar saling menghargai.

d. Program ini dapat membantu peserta didik yang lemah atau yang mengalami kesulitan dalam memahami materi belajar, sedangkan peserta didik yang pandai dapat mengembangkan kemampuan dan keterampilannya.

e. $\quad$ Adanya rasa tanggung jawab kelompok dalam menyelesaikan masalah.

f. Menghemat presentasi pendidik sehingga waktu pembelajaran lebih efektif.

Kekurangan model pembelajaran kooperatif tipe TAl yaitu :

a. $\quad$ Peserta didik yang kurang pandai secara tidak langsung akan menggantungkan dirinya pada peserta didik yang pandai.

b. Adanya anggota kelompok yang pasif dan tidak mau berusaha serta hanya mengandalkan teman sekelompoknya.

c. Apabila model pembelajaran ini merupakan model pembelajaran yang baru diketahui, kemungkinan sejumlah peserta didik bingung, sebagian kehilangan rasa percaya diri dan sebagian mengganggu antar peserta didik lain.

d. Pengelolaan kelas yang dilakukan oleh pendidik kurang baik maka proses pembelajarannya juga berjalan kurang baik.

Belajar merupakan proses dalam diri individu yang berinteraksi denga lingkungan untuk mendapatkan perubahan dalam perilakunya. Belajar adalah aktivitas mental/psikis yang berlangsung dalam interaksi aktif dengan lingkungan yang menghasilkan perubahan-perubahan dalam pengetahuan, keterampilan dan sikap (Purwanto, 2009).

Hasil belajar seringkali digunakan sebagai ukuran untuk mngetahui seberapa jauh seseorang menguasai bahan yang sudah diajarkan untuk mengaktualisasikan hasil belajar tersebut diperlukan 
serangkaian pengukuran menggunakan alat evaluasi yang baik dan memenuhi syarat. Pengukuran demikian dimungkinkan karena pengukuran merupakan kegiatan ilmiah yang dapat diterapkan pada berbagai bidang termasuk pendidikan. Hasil belajar dapat dielasskan dengan memahami dua kata yang membentuknya, yaitu 'hasil' dan "belajar". Pengertian hasil (product) menunjuk pada suatu perolehan akibat dilakukannya suatu aktivitas atau proses yang mengakibatkan berubahnya iput secara fungsional. Hasil produksi adalah perolehan yang didaptkan karea adanya kegiatan mengubah bahan (raw materials) menjadi barang jadi (finished goods). Hal yang sama berlaku untuk memberikan batasan bagi istilah hasil panen, hail penjualan, hasil pembangunan, termasuk hasil belajar. Dalam siklusi input akibat perubahan oleh proses. Begitu pula dalam kegiatan belajar mengajar, setelah mengalami belajar peserta didik berubah perilakunya dibanding sebelumnya (Purwanto, 2009).

Hasil belajar adalah kemampuan yang diperoleh anak setelah melalui kegiatan belajar. Belajar itu sendiri merupakan suatu proses dari seseorang yang berusaha untuk memperoleh suatu bentuk perubahan perilaku yang relativ menetap. Dalam kegiatan pembelajaran atau kegaiatn instruksional, biasanya pendidik menetapkan suatu pembelejaran atau tujuan instruksional (Jihad \& Haris, 2012).

Menurut Benjamin S. Bloom (Jihad \& Haris, 2012) tiga ranah (domain) hasil belajar, yaitu kognitif, afektif dan psikomotoik. Menurut A.J. Romizowski (Jihad \& Haris, 2012) hasil belajar merupakan keluaran (outputs) dari suatu sistem pemrosesan masukan (input). Masukan dari sistem tersebut berupa bermacam-macam informasi sedangkan keluarannya adalah perbuatan atau kinerja (performance).

Berdasarkan Hasil Penelitian Dari Beberapa Peneliti Tentang Pengaruh Model Pembelajaran Kooperatif Tipe Team Assisted Individualization (TAI) terhadap hasil belajar dilihat dari hasil penelitian Asriningsih et al (2014) bahwa data hasil belajar IPA pada kelompok siswa yang dibelajarkan dengan model pembelajaran kooperatif tipe Team Assisted Individualization (TAI) cenderung tinggi dibanding dengan siswa yang dibelajarkan dengan model konvensional. Hasil penelitian tersebut sesuai dengan hasil penelitian yang dilakukan oleh Wardani et al (2014) Model pembelajaran kooperatif tipe TAI memberikan pengaruh positif terhadap hasil belajar IPA peserta didik dimana siswa yang dibelajarkan melalui model pembelajaran kooperatif tipe TAl lebih tinggi dari hasil belajar IPA peserta didik yang dibelajarkan melalui pembelajaran konvensional dan (Sitanggang \& Sirait, 2015; Amarendra, 2015) Ada pengaruh yang signifikan terhadap model pembelajaran kooperatif tipe TAl terhadap hasil belajar.

Dengan demikian, diadakan penelitian untuk mengetahui pengaruh model pembelajaran kooperatif tipe Team Assisted Individualization (TAI) terhadap hasil belajar peserta didik kelas VIII SMP Negeri 18 Makassar. Rumusan masalah yang digunakan pada penelitian ini yaitu, "Adakah pengaruh model pembelajaran kooperatif tipe Team Assisted Individualization (TAI) terhadap hasil belajar peserta didik kelas VIII SMP Negeri 18 Makassar?”

\section{METODE PENELITIAN}

Jenis penelitian yang digunakan dalam penelitian ini ialah Quasi-eksperiment dengan menggunakan desain Pretest-Posttest Nonequivalent Control Group Design. Penelitian ini dilaksanakan di SMP Negeri 18 Makassar. Populasi penelitian adalah seluruh kelas VIII SMP Negeri 18 Makassar tahun ajaran 2016/2017 yang terdiri dari sepuluh kelas dengan jumlah peserta didik sebanyak 285 orang. Pemilihan sampel dilakukan dengan teknik double random sampling sehingga diperoleh dua kelas sampel yakni kelas VIII.8 sebagai kelas eksperimen dan kelas VIII.9 sebagai kelas kontrol.

Teknik pengumpulan data dilakukan dengan pemberian tes hasil belajar berupa pilihan ganda yang terdiri dari 25 item yang selanjutnya data akan dianalisis statistik deskriptif dan analisis statistik inferensial. 


\section{HASIL DAN PEMBAHASAN}

\section{A. Hasil Penelitian}

Hasil belajar pada kelas eksperimen dengan menggunakan model pembelajaran kooperatif tipe Team Assisted Individualization (TAl) mengalami peningkatan yang tinggi daripada kelas kontrol yang diajar dengan model pembelajaran konvensional. Nilai hasil belajar yang dimaksud adalah skor total hasil tes yang berbentuk tes pilihan ganda pada ranah kognitif $\mathrm{C}_{1-\mathrm{C} 4}$ yang diperoleh peserta didik baik pada kelas eksperimen maupun pada kelas kontrol.

Tabel 1. Skor Posttest Hasil Belajar pada Kelas Eksperimen dan Kelas Kontrol Peserta Didik Kelas VIII SMP Negeri 18 Makassar

\begin{tabular}{ccc}
\hline Data & Kelompok Eksperimen & Kelompok Kontrol \\
\hline Jumlah Sampel & 30 & 30 \\
Skor Tertinggi & 24 & 24 \\
Skor Terendah & 14 & 14 \\
Skor Rata-rata & 19,93 & 18,43 \\
Standar Deviasi & 2,52 & 2,25 \\
Varians & 6,38 & 5,09 \\
\hline
\end{tabular}

Jumlah perolehan skor peserta didik pada kelas eksperimen dan kelas kontrol dapat dilihat berdasarkan pengkategorian skor yang disajikan pada tabel berikut.

Tabel 2. Kategori skor Posttest Hasil Belajar Peserta Didik Kelas Eksperimen dan Kelas Kontrol

\begin{tabular}{|c|c|c|c|}
\hline \multirow{2}{*}{ Rentang Skor } & \multirow{2}{*}{ Kategori } & \multicolumn{2}{|c|}{ Frekuensi } \\
\hline & & Kelas Eksperimen & Kelas Kontrol \\
\hline $21-25$ & Sangat Tinggi & 12 & 5 \\
\hline $16-20$ & Tinggi & 16 & 24 \\
\hline $11-15$ & Sedang & 2 & 1 \\
\hline $6-10$ & Rendah & 0 & 0 \\
\hline $0-5$ & Sangat Rendah & 0 & 0 \\
\hline \multicolumn{2}{|c|}{ Jumlah } & 30 & 30 \\
\hline
\end{tabular}

Tabel 2 menunjukkan bahwa adanya perbedaan nilai posttest pada kelas eksperimen dan kelas kontrol, dimana pada kelas eksperimen terdapat peningkatan dibandingkan pada kelas kontrol.

Tingkat pencapaian indikator pemahaman konsep pada kelas eksperimen lebih tinggi dibandingkan pada kelas kontrol. Hal ini ditunjukkan pada Tabel 3 berikut.

Tabel 3. Gambaran Persentase Pencapaian Indikator Hasil Belajar Peserta Didik

\begin{tabular}{cc}
\hline Kelas & Persentase Pencapaian Indikator Hasil Belajar \\
\hline Eksperimen & $82,56 \%$ \\
Kontrol & $76,43 \%$ \\
\hline
\end{tabular}

Uji normalitas yang digunakan pada penelitian ini ialah uji chi-kuadrat. Hasil uji normalitas dapat dilihat pada Tabel 4 berikut. 
Tabel 4. Data Hasil Uji Normalitas

\begin{tabular}{cccl}
\hline Data & Eks & Kon & $\begin{array}{l}\text { Keterangan } \\
X_{\text {hitung }}^{2}<X^{2}{ }_{\text {tabel }}\end{array}$ \\
\cline { 1 - 3 } $\mathrm{N}$ & 30 & 30 & \\
$X_{\text {hitung }}^{2}$ & 2,90 & 6,20 & Normal \\
$X_{\text {tabel }}^{2}$ & 11,07 & 11,07 & Normal \\
\hline
\end{tabular}

Berdasarkan tabel 4 diketahui bahwa $X^{2}$ hitung kelas eksperimen dan kelas kontrol kurang dari $X_{\text {tabel. }}^{2}$ Berarti hasil uji normalitas pada penelitian ini adalah data sampel berasal dari populasi berdistribusi normal.

Tabel 5. Data Hasil Uji Homogenitas

\begin{tabular}{lcccc}
\hline Data & $\boldsymbol{a}$ & $\mathbf{F}_{\text {hitung }}$ & $\mathbf{F}_{\text {tabel }}$ & $\begin{array}{c}\text { Keterangan } \\
\mathbf{F}_{\text {hitung }} \leq \mathbf{F}_{\text {tabel }}\end{array}$ \\
\hline Eks & 0,05 & 1,5 & 1,86 & Homogen \\
Kon & 0,05 & & & \\
\hline
\end{tabular}

Uji homogenitas digunakan untuk mengetahui apakah kedua kelompok data yang diteliti berasal dari populasi yang homogen atau tidak, dengan kriteria $F_{\text {hitung }}<F_{\text {tabel, }}$ maka data berasal dari populasi homogen. Berdasarkan Tabel 5 dapat diketahui bahwa data hasil belajar peserta didik yang mengikuti pembelajaran dengan model pembelajaran kooperatif tipe TAI dan peserta didik yang mengikuti pembelajaran konvensional memiliki taraf nyata 0,05 yang berarti Ho diterima, yang berarti tidak ada perbedaan varians antara data hasil belajar peserta didik menggunakan model pembelajaran kooperatif tipe TAI dan pembelajaran konvensional atau kedua populasi memiliki varians yang sama. Berdasarkan hasil uji prasyarat, disimpulkan bahwa kedua kelompok data berasal dari populasi yang berdistribusi normal dan homogen, maka uji hipotesis menggunakan ujit.

Tabel 6. Data Hasil Uji Hipotesis

\begin{tabular}{cccc}
\hline Data & $\mathbf{t}_{\text {hitung }}$ & $\mathbf{t}_{\text {tabel }}$ & $\begin{array}{c}\text { Keterangan } \\
\mathbf{t}_{\text {hitung }}>\mathbf{t}_{\text {tabel }}\end{array}$ \\
\hline & 4,67 & 1,67 & $\mathrm{H}_{0}$ ditolak dan $\mathrm{H}_{\mathrm{a}}$ \\
$\mathrm{a}$ & 0,05 & diterima \\
\hline
\end{tabular}

Kriteria pengujian hipotesis adalah jika $t_{\text {hitung }}>t_{\text {tabel, }}$, maka $H_{\circ}$ ditolak dan jika $t_{\text {hitung }}<t_{\text {tabel }}$ maka $\mathrm{H}_{\mathrm{o}}$ diterima. Hasil uji-t hasil belajar diperoleh pada saat pemberian pretest posttest yakni thitung $>$ $t_{\text {tabel }}$ yang berarti $\mathrm{H}_{0}$ ditolak dan $\mathrm{H}_{\mathrm{a}}$ diterima. Oleh karena itu, dapat disimpulkan bahwa terdapat pengaruh model pembelajaran kooperatif tipe Team Assisted Individualization (TAI) terhadap hasil belajar Peserta Didik Kelas VIII SMP Negeri 18 Makaassar (Studi pada Materi Pokok Alat Optik).

Data yang diperoleh pada analisis lembar observasi keterlaksanaan model pembelajaran kooperatif tipe Team Assisted Individualization (TAI) yaitu pada pertemuan pertama 100\%, pertemuan kedua $100 \%$, dan pertemuan ketiga 100\%. Dari data tersebut menunjukkan bahwa semua langkah dalam pembelajaran terlaksana sesuai dengan model pembelajaran. 


\section{B. Pembahasan}

Penelitian ini dimaksudkan untuk mengetahui pengaruh model pembelajaran kooperatif tipe Team Assisted Individualization (TAI) terhadap hasil belajar peserta didik kelas VIII SMPN 18 Makassar studi pada materi pokok alat optik. Sebelum dilakukannya penelitian terlebih dahulu tes hasil belajar di uji empiris pada kelas X MIA 1 dimana pada hasil analisis diperoleh bahwa dari 30 item soal yang diuji cobakan terdapat 25 item soal yang valid dan 5 invalid. Untuk mengetahui pengaruh pembelajaran tersebut, diambil dua kelas sebagai kelompok sampel yaitu kelas eksperimen dan kelas kontrol. Kelas eksperimen dilakukan pembelajaran dengan model pembelajaran kooperatif tipe Team Assisted Individualization (TAI) sedangkan kelas kontrol dilakukan pembelajaran dengan model pembelajaran konvensional. Dari kedua kelas tersebut diberikan pretest dan posttest.

Berdasarkan analisis statistik secara deskriptif terlihat bahwa pemahaman konsep peserta didik kelas VIII SMPN 18 Makassar pada kelas eksperimen dan berbeda pada kelas kontrol. Hal ini dapat dilihat dari skor rata-rata yang diperoleh, dimana skor rata-rata populasi kelas eksperimen termasuk dalam kategori tinggi, nilai rata-rata populasi kelas kontrol termasuk kategori sedang. Untuk lebih jelasnya dapat dilihat pada tabel 4.2.

Untuk memperkuat hasil analisis deskriptif diatas maka dilakukan analisis statistik inferensial untuk membuktikan hipotesis yang diajukan. Dengan demikian diperoleh hasil analisis Uji-t, membuktikan bahwa pada pretest $\mathrm{H}_{\mathrm{o}}$ diterima dan $\mathrm{H}_{\mathrm{a}}$ ditolak dan pada posttest $\mathrm{H}_{\mathrm{o}}$ ditolak dan $\mathrm{H}_{\mathrm{a}}$ diterima yang berarti bahwa terdapat perbedaan hasil belajar peserta didik yang diajar menggunakan model pembelajaran kooperatif tipe Team Assisted Individualization (TAI) dan yang diajar dengan model pembelajaran konvensional.

Kerangka pikir pada awal penelitian menunjukkan optimisme peneliti melihat akan adanya perbedaan hasil belajar yang terbangun pada pembelajaran yang menggunakan model pembelajaran kooperatif tipe Team Assisted Individualization (TAI) dengan pembelajaran menggunakan model konvensional yang diterapkan di SMPN 18 Makassar. Hal ini terbukti peserta didik yang diberi perlakuan mampu memperlihatkan keseriusan dan semangat dalam belajar. Hal ini ternyata berdampak pada hasil hasil belajar peserta didik. Dan akhirnya diperoleh bahwa pembelajaran dengan menggunakan model pembelajaran kooperatif tipe Team Assisted Individualization (TAI) memberikan hasil belajar yang berbeda daripada pembelajaran dengan model konvensional.

Perbedaan ini tidak terlepas dari adanya efek perlakuan pada kelas eksperimen, dimana pada penggunaan model TAI, pendidik berusaha menekankan aktivitas peserta didik secara maksimal dalam proses belajar mengajar. Seluruh aktivitas yang dilakukan peserta didik diarahkan untuk mencari dan menemukan jawaban sendiri dari suatu yang dipertanyakan, dengan memanfaatkan tutor sebaya dimana tutor sebaya tersebut harus mampu membantu temannya yang masih di bawah rata-rata. Adapun tutor sebaya dipilih berdasarkan kemampuannya, di mana tutor tersebut memang memiliki kemampuan kognitif diatas rata-rata.

Indikator yang diharapkan dapat dipahami oleh peserta didik, hasil analisis menunjukkan bahwa peserta didik lebih mudah memahami tes hasil belajar yang diajarkan menggunakan model pembelajaran kooperatif tipe TAI. Pencapaian indikator hasil belajar ditunjang oleh keterlaksanaan pembelajaran, hal ini disebabkan karena pencapaian pada keterlaksanaan pembelajaran mencapai persentase $100 \%$. Hal ini menujukkan bahwa semua langkah pada pembelajaran dilakaksanakan pada proses mengajar.

Berdasarkan uraian tersebut, maka tampak bahwa pengaruh model pembelajaran Kooperatif tipe Team Assisted Individualization (TAI) dapat meningkatkan hasil belajar peserta didik sehingga dapat dijadikan alternatif dalam proses pembelajaran. Hasil penelitian ini selaras dengan hasil-hasil penelitian terdahulu yang telah dilakukan seperti Wulandari (2014) dan Hidayatullah (2015). 


\section{KESIMPULAN}

Berdasarkan hasil penelitian yang telah dilakukan dapat disimpulkan bahwa ada pengaruh model pembelajaran kooperatif tipe Team Assisted Individualization (TAI) terhadap hasil belajar peserta didik. Hasil belajar peserta didik yang dibelajarkan dengan menggunakan model pembelajaran ini berada pada ketegori tinggi dan hasil belajar peserta didik yang dibelajarkan dengan model pembelajaran direct instruction berada pada kategori sedang.

\section{DAFTAR PUSTAKA}

Amarendra, G. V. 2015. Pengaruh Model Pembelajaran Kooperatif Tipe Team Assisted Individualization (TAI) Dengan Menggunakan Strategi Elaborasi Pada Mata Pelajaran Instalasi Tenaga Listrik Untuk Meningkatkan Hasil Belajar Siswa di Kelas XI Teknik Instalasi Pemanfaatan Tenaga Listrik di SMK Negeri 5 Surabaya. Jurnal Pendidikan Teknik Elektro. Vol 04. No. 03.

Hidayatullah, R. 2015. Peningkatan Hasil Belajar Siswa Kelas XI Pada Mata Pelajaran Instalasi Penerangan Listrik Dengan Mengimplementasikan Model Pembelajaran Kooperatif Tipe TAI (Team Assisted Individualization) di SMK Negeri 3 Jombang. Jurnal Pendidikan Teknik Elektro. Vol 04. No. 01.

Huda, M. 2013. Model-Model Pengajaran dan Model Pembelajaran. Yogyakarta: Pustaka Belajar.

Jihad, A. \& Haris, A. 2012. Evaluasi Pembelajaran. Yogyakarta: Multi Pressindo.

Purwanto. 2009. Evaluasi Hasil Belajar. Surakarta: Pustaka Belajar.

Slavin, R. E. 2005. Cooperative Learning Teori, Riset, dan Praktik. Bandung: Nusa Media.

Slavin, R. E. 2009. Cooperative Learning: Teori, Riset, dan Praktik. Bandung: Nusa Media.

Taniredja, T., Faridli, M.,\& Harmianto, S. 2012. Model Pembelajaran Inovatif dan Efektif. Bandung: Alfabeta.

Wardani, C. A. et al. 2014. Pengaruh Model Pembelajaran Team Assisted Individualization (TAI) Terhadap Hasil Belajar Mata Pelajaran IPA Pada Siswa Kelas VII Tahun Ajaran 2014/2015 di SMP Negeri 1 Banjar. Jurnal Edutech. Vol 2 No. 1.

Wulandari, P. Y. et al. 2014. Pengaruh Penerapan Model Pembelajaran Kooperatif Tipe Team Assisted Individualization (TAI) Terhadap Hasil Belajar IPA Siswa Kelas V SD Gugus VIII Kedewatan Kecamatan Ubud Gianyar. E-Jurnal Mimbar PGSD Universitas Pendidikan Ganesha. Jurusan PGSD Vol 2 No. 1.

Received 20 May 2018

Accepted, 25 February 2019

Sudarto

Dosen

Ratnawaty Mamin

Dosen

Erika Nadya Nastiti

Alumni Program Studi Pendidikan IPA FMIPA UNM 